XV.--On Branchiura sowerbyi Beddard, and on a new species of Limnodrilus with distinctive characters. By J. Stephenson, M.B., D.Sc. (Lond.), Major, Indian Medical Service; Professor of Biology, Government College, Lahore. Communicated by Professor Ewart. (With Two Plates.)

(MS. received October 25, 1911. Read December 4, 1911. Issued separately May 23, 1912.)

On a recent occasion, looking into a small shallow pool near Lahore, I saw here and there on its bottom a reddish appearance, which a closer examination showed to be due to innumerable worms, implanted by one extremity in the mud, and waving their free ends in the water. These were the Limnodrilus described below. A quantity of the mud taken for further examination yielded, though in very much smaller numbers, three other Oligochætes, viz. Branchiura sowerbyi, Lahoria hortensis, and a species of Dero.

Branchiura sowerbyi was originally described by BEDDARD (2) from specimens found in mud from the "Victoria regia tank" in the Royal Botanical Society's Gardens, Regent's Park. Its most distinctive feature is the possession of a double series of finger-like gills on the posterior part of the body, one row being placed along the middorsal, the other along the mid-ventral line. Lahoria hortensis was originally described by me (9) from a small pond in the Lawrence Gardens at Lahore; it is not common; and, not having met with it for two years, I had begun to think that it had disappeared. It belongs to the Naididæ; like Branchiura sowerbyi, it possesses two rows of gillprocesses, but these are either limited to, or best developed on, the anterior part of the body, and are dorso-lateral in position. Dero is well known as a Naid which possesses a small number of gill-processes at the posterior end of the body round the anus. Limnodrilus is remarkable in possessing a cutaneous capillary plexus in the posterior part of its body,- - better marked in this, apparently, than in most of the other species of the genus; and this feature, and the constant waving movements of its tail, have doubtless a respiratory signiticance.

There were here, therefore, living together, four genera of Oligochætes, with peculiar and specialised respiratory arrangements; and, by a curious coincidence, three of them were among the very few known Oligochætes which possess gills.

The coincidence, however, does not end here. BEDDARD, in his paper on Branchiura sowerbyi, relates that the mud which provided him with this form also contained three or four examples of Chatobranchus semperi, a gilled Naid previously described from Madras by Bounne (4). Branchiura sowerbyi has been recorded twice since then (1892) (v. inf.), but Chrtobranchus has apparently not been seen again. Lahoria, however, resembles Chætobranchus very closely in many ways, ${ }^{*}$ the chief difference

* Michaelser (7) indeed includes it in the genus Branchiodrilus, Mchlsn. (=Chrtobranchus, Bourne). I have discussed the question in my original paper (9) ; the point depends on the value to be attached to "cephalisation,"

TRANS. ROY. SOC. EDIN., VOL. XLVIII. PART II. (NO. 15). 
being the absence in Lahoria of gills and dorsal setæ on the segments from the second to the fifth, and their presence on these segments in Chrtobranchus. It is thus noteworthy that the coexistence of Branchiura sowerbyi and Chxtobranchus in artificial surroundings in England should be paralleled by the coexistence of Branchiurce sowerbyi and Lahoria under natural conditions in India.

The pond in which the worms were found was one of a series occurring in a small nullah on the outskirts of Lahore. The surface drainage of the jail runs into this nullah, so that, unlike most small ponds in this neighbourhood, it is probably seldom altogether dry. At times, e.g. after rain, there is a continuous stream of water along the nullah.

Methods. - 'The best method for the observation of the living animals is the employment of the binocular microscope with comparatively low powers; this is the easiest way of obtaining a conception of the complicated relationships of the blood-vessels, and the mode of their contraction.

'The setæ are best studied by killing the animals by a narcotic (methyl alcohol, chloretone) and leaving them in the water for a few hours till they become soft and are just beginning to disintegrate. A worm is then carefully placed on a slide in glycerin and the coverglass lowered; the weight of the coverglass is sufficient to cause a specimen in this condition to flatten out completely, and the setæ, retaining their arrangement, can then be viewed in one plane.

Parts of the genital system, and especially the chitinous penis sheath of the Limnodrilus, can be isolated by teasing under the binocular microscope.

Serial sections $(5-10 \mu)$ were stained with Heidenhain's iron-hæmatoxylin followed by eosin, and with Delafield's hæmatoxylin.

\section{Branchiura sowerbyi Bedd.}

Since the original discovery of this worm by BEDDARD it has been recorded by $\mathrm{J}$. Perrier (8), who has found it in different years at several places in the Rhone at Touron (Ardèche), and by Michaelsen (6) in a warm-water tank of the Botanical Gardens at Hamburg. Perrier does not give any anatomical description of his specimens, while MICHALLSEN states that, apart from the genital apparatus, which he describes in detail, his specimens agree essentially with BEDDARD's.

I do not propose to give a complete description of the worm. My own specimens

i.e. the differentiation of a certain number of the anterior segments of the body,-especially their differentiation by the absence from them of the doreal series of sete. The presence or absence of this cephalisation has hitherto, I think, always been regarded as of generic importance, and the extent anteriorly of the dorsal setic is always mentioned in the generic diagnoses of the Naidide; and so Bourne, Beddard (3), and MrCHakLSEN (5) all give the distribution of the dorsal setze (as far forwards as the second segment) as a generic character of Chætobranchus.

It is, I think, very possible, as I have myself suggested, that cephalisation will lose much of the importance hitherto assigned to it. But until the question has been further discussed, and until authorities are agreed with respect to this far-reaching alteration in our ideas as to specific and generic characters in the Naididæ, it seems better to abide by the more general opinion on this point. 
were none of them mature sexually, so that a comparison with BEDDARD's and Michatelsen's specimens is in this respect impossible. I wish, however, to refer in some detail to the setæ, the gills, the body-wall, the coelom and its partitions, the circulatory and nervous systems; and to bring out certain points which are new, or in which my specimens appear to differ from those described by BEDDARD.

Seven specimens of this worm were obtained. In length they were, when extended, two inches or less, i.e. considerably longer than those examined by BEDDARD ; one, much the smallest, measured only about two-thirds of an inch. They were fairly stout, in breadth about a millimetre or more, very contractile, with both ends tapering to a blunt point. In colour they were a pinkish grey, with whiter and more translucent margins.

The prostomium is bluntly conical ; the number of segments 74-116.

The setæ are of three kinds, single and double-pointed needles, and hair-setæ ; the needles of both forms occur in both dorsal and ventral bundles, the hair-setæ only in the dorsal.

The needle-setæ (fig. 1) are mostly forked in the anterior part of the body, singlepointed needles being relatively few; in the posterior bundles the reverse is the case, the single-pointed being here the more numerous. In the double-pointed setæ the outer point, i.e. that on the outer side of the curve of the shaft, is the smaller; intermediate forms between the single- and double-pointed setæ are met with, in which the outer point is still smaller, or, it may be, scarcely recognisable. The single-pointed setæ and the intermediate forms are not produced from the forked setæ by wear, since, especially in the posterior part of the body, the formation of new setre may be observed, and many of these have single points from the beginning. In length these needle-setæ are about $120 \mu$, in breadth $6-7 \mu$; they have the usual double curve; the nodulus, not mentioned by BEDDARD, is distal to the middle of the shaft (distal to nodulus:proximal to nodulus::2:3); and the seta ends internally by tapering somewhat, not as shown by BEDDARD in a broad square end.

The hair-setæ are a little longer $(130-164 \mu)$ and much slenderer than the needles; they are straight, and show no other distinctive marks; they are confined to the dorsal bundles of the anterior part of the body, being absent from the whole of the gill-region ; there is never more than one in each setal bundle.

The setal bundles begin both dorsally and ventrally in the second segment, and cease some distance in front of the hinder end of the animal, the last ten segments or so being devoid of setæ. There may be as many as six needle-setæ in a ventral bundle; five, four, or fewer are also met with. In the dorsal bundles the most that $I$ have observed is five needles and one hair-seta.

The gills correspond in their appearance to the description given by BEDDARD. They are not ciliated, are situated along the mid-dorsal and mid-ventral lines, and occupy the posterior fourth to two-fifths of the animal's length. 'There were from 38 to 55 pairs, on a corresponding number of segments. In length they are about equal to the diameter of the body, but they diminish in size towards the anterior, and less 
markedly towards their posterior limit; anteriorly, before fading away completely, they become mere tubercles. They are in constant movement, in some degree reminding the observer of cilia; the resemblance is frequently increased by the regular propagation of the beat along the line of the gills, in a postero-anterior direction, like the propagation of a ciliary wave; but there is this difference, that the movement of the individual gills is a swinging movement from side to side, i.e. in a direction at right angles to the direction of propagation of the wave, not, as in the case of ciliary movement, in the same direction as the wave. The structure of the gills will be described with that of the body-wall.

In addition to the oscillations of the gills themselves, the whole posterior part of the body of the worm is continually performing undulatory movements.

The body-wall (figs. 2-5) consists of the usual layers. The surface epithelium is high and columnar over the body generally, low over the gills (fig. 6). The subjacent circular muscular layer is thin, and extends unbroken throughout the body. The longitudinal muscular layer, on the other hand, is thick, but is characterised by inequalities of distribution ; in the anterior part of the body (fig. 2) it is of the same thickness at all parts of the body-circumference, but in the gill region inequalities appear, while posteriorly (fig. 3) it is absent from parts of the body-wall. The position of the bands of fibres that persist varies : they may be lateral, one on each side; or one dorsal and one ventral; or there may be one, a ventro-lateral, band only. The position of the absent fibres is taken by an indefinite network with a few cells, the appearance being somewhat that of a scaffolding or meshwork from which the fibres have dropped out.

An inner circular layer of muscular fibres is well marked in the anterior part of the body (fig. 2). The muscular fibres of the septa are continuous with the fibres of this layer; and special bundles of fibres, passing vertically between the sacs of the dorsal and ventral setæ on the same side, may be considered as belonging to it ( $c f$. also Limnodrilus socialis, post).

In the gill region the circular muscular layer of the body-wall is continued over the gills without splitting, while the longitudinal layer closes the base of the space within the gill, the fibres maintaining their straight course without being deflected. In the interior of the gill, within its muscular layer, are a number of branched cells whose processes anastomose ( $\alpha$, fig: 6 ) ; these may entirely fill the distal part of the gill-cavity. Proximally, near the base of the gill, there is always a space; cells and cell-processes may stretch across it, and other cells may form a definite, almost epithelial layer on the inner surface of the muscular coat (fig. 6). The two vessels of the gill run on opposite sides, within the muscular coat.

BEDDARD, who describes a septum shutting off the cavity of the gill from the general body-cavity, nevertheless speaks of the gill-cavity as "evidently belonging to the coelom." I do not think this follows either from his description or mine; the gillcavity appears to be a space between the muscular layers of the body-wall, which undergo a separation consequent on the circular layer alone being continued over the gill. BEDDARD also states that the movements of the branchiæ are caused by muscular 
fibres, elongated, fusiform, with central nucleus, or sometimes branched and star-shaped, which traverse the cavity of the branchia from side to side. These fibres are obviously the branched cells which I have described above; but I can find no reason to suppose that they are muscular, either in BEDDARD's description or my own preparations. On the one hand, the observed movements of the gills could not be accounted for by the contraction of such fibres; while, on the other hand, all the movements shown by the gills in my specimens could be caused by a contraction, on one or other side of the gill, or on both sides simultaneously, of the fibres derived from the circular muscular coat.

A fairly obvious feature in the constitution of the body-wall is the lateral line. It. exists on each side within the circular muscular layer as an aggregation of cells, which in its situation and in its relation to the longitudinal muscular layer recalls the similar structure in the Nematodes. The circular muscular layer is continuous over the line of cells, but the longitudinal layer is completely divided by it on each side (figs. 2, 3, 4). The cells are of somewhat small size, their outlines indistinct, their nuclei ovoid or spindleshaped. The line extends, midway between dorsal and ventral rows of setæ, from the third or fourth segment to within a few segments of the posterior end. It is easily followed in transverse sections; its nature can also be seen in vertical sections where the lateral body-wall is cut tangentially; the line of cells is seen to form a continuous track, of uniform width, in the substance of the longitudinal muscular layer. The line is continuous, however, only as far back as the anterior gill-region; behind this it is interrupted, and consists of a series of segmentally arranged groups of cells in the posterior part of each segment in front of the septum. Near the posterior end of the body the groups of cells, as seen in transverse sections, project further inwards and spread out somewhat in the body-cavity (fig. 4). The lateral line is also the situation from which numerous bundles of muscular fibres arise.*

The colom and its partitions. - The partitions which separate off the cavities in the gills, and the question of the colomic nature of these latter, have already been considered.

'The septa are extremely thick and muscular in the anterior part of the body (fig. 2). The first septum is $\frac{3}{4}$; from here onwards to $\frac{9}{10}$ the septa have the above character $; \frac{10}{11}$ and all succeeding septa are thin; they contain, however, muscular fibres, both radial and circular.

BEDDaRD states that "there appears always to be a partition which shuts off the upper part of the coelom from the lower part" (he is speaking of the branchial region); the upper cavity he found "exclusively occupied by the intestine, the lower cavity by the nervous system and the principal blood-vessels ;" in his figure the partition is shown as a thin peritoneal membrane, on which are a number of nuclei.

I do not find any partition of this nature in my specimens. There are, however, in the branchial region a number of well-defined, fairly thick bands, which pass across from one lateral line to the other. These do not form a continuous sheet, but have a

\footnotetext{
* For the most recent contribution on the subject of the lateral line, $v$. H. PoINTNer, "Beiträge zur Kenntnis der Oligochætenfaunx der Gewässer von Graz," Zeit.f. wiss. Zool., Band xcviii., Heft 4, 1911.
} 
segmental arrangement, being present for some distance in front of each septum (fig. 5). In this situation, moreover, the intestine and dorsal vessel are above, the nerve cord and ventral vessel below the band.

Other muscular strands are also to be seen ( $c f$. fig. 5) : thus fibres may be observed passing from the transverse bands in an oblique direction downwards to the body-wall. There are, in addition, a number of strands in the upper part of the body-cavity which pass between the intestine and the parjetes; these appear to be each constituted by a single cell, with a large ovoid nucleus situated to one side of the strand.

In the most posterior part of the body the ventral portion of the coelom may be completely filled by the blood-vessels, nerve cord, and a number of cells and fibres, so that there is here no free space below the level of the transverse bands (fig. 5).

Circulatory system. - The dorsal vessel is, as described by BEDDARD, not dorsal at all for the greater part of its course; it is situated ventrally, or rather ventro-laterally on the left side (figs. 3, 8), or it may be in places directly on the left of the intestine (fig. 5). Though not lying immediately on the intestinal wall, it has nevertheless a closer relation to the gut and to the chloragogen cells than has the ventral vessel, and the branches which unite it with the plexus on the intestine are much shorter than those which connect the plexus with the ventral vessel (fig. 8). In sections it is as a rule larger than the ventral vessel. It passes up the left side of the alimentary canal in the eleventh and tenth segments, and thenceforward is dorsal in position. In life it is contractile.

The ventral vessel (figs. 3,5 ) is on the right of the dorsal in the posterior part of the body; it lies on or near the nerve cord; it is connected by numerous vessels with the intestinal plexus. Anteriorly it is formed by the union of the hearts. Its place is taken in front of the ninth segment by a trunk which is formed in segment $v$ by the union of two vessels coming from the anterior end of the body, and presumably originating in the forking of the front end of the dorsal vessel ; this 'anterior ventral' vessel receives the lateral loop vessels on each side, including the large loops in segment viii from the supra-intestinal; very soon thereafter it becomes enveloped in the chloragogen cells and disappears on the ventral surface of the alimentary canal.

There is a rich intestinal plexus in the gut-wall, which in segments $\mathrm{x}$-xiii becomes almost a sinus; sections through this region frequently show a continuous blood-space all round the circumference of the alimentary tube. Besides the connections with dorsal and ventral vessels, the plexus is joined to the supra-intestinal by a series of wide communications.

Owing to the comparatively large size and consequent opacity of my specimens during life, it was not easy to trace out in the living worms all the details of the course of the vessels to the gills and body-wall. Fig. 7 represents what could be seen; and in addition I have worked out the point in sections (fig. 8). In the gill-region the dorsal vessel gives in each segment two branches, one dorsalwards, on the inner surface of the body-wall (d.d.), which gives a twig across the mid-dorsal line and then enters 
the dorsal gill; and one ventralwards (c.d.), with a similar course and distribution on the ventral side. The two branches may, in the region of the anterior gills, arise in common (fig. 7). The ventral vessel gives two branches: one goes to the right and bifurcates almost immediately into two divisions, which correspond to the two branches of the dorsal vessel, - - one running dorsalwards on the inside of the body-wall to the dorsal gill (d.lr.v.), the other taking a short course ventralwards to the ventral gill (v.brv. .). The second branch of the ventral vessel (l.brvv.), leaving the main trunk on the left side of the latter, arches over the nerve cord and goes to the left side of the body-wall; it gives a branch to the right below the nerve cord, which seems, according to sections, sometimes at least to meet and anastomose with the branch from the ventral vessel to the ventral gill; thus in these cases a ring is formed round the ventral nerve cord.

I am not satisfied that the arrangement above described is constant; in one series of sections the two vessels going to the dorsal gill were derived, one from the dorsal vessel in the usual way, described above, and the other from the branch from the ventral vessel to the left side of the body-wall (i.e. the dorsally directed branch of the vessel $l . b r: v$. in fig. 8 went up into the gill).

In front of the gills the parietal vessels have the form of lateral loops, two per segment,--one on the anterior face of the septum, the other more anteriorly in the segment. There are also, as described by BEDDARD, a number of longitudinal vessels, some of which connect successive loops, while others, smaller, pass over several segments at least. The muscular layers of the body-wall are penetrated by numerous twigs, but no capillaries seem ever to enter into the surface epithelium.

The supra-intestinal vessel is hardly or not at all distinguishable in front of the sixtl segment, and it is small as far back as segment viii; here two considerable loops, one on each side, put it in connection with the 'anterior ventral' vessel ; these loops, though not as large as the hearts in the next segment, are still extremely conspicuous structures. In segment ix it gives rise to the first pair of hearts, and in the same segment a number of vessels radiate from it across the body-cavity to the parietes. In this part of its extent it lies directly beneath the dorsal vessel, and, like the latter, gets round to the left side in the posterior part of its course. It is largest in segments $x$ and $\mathbf{x i}$; it communicates by wide channels with the intestinal plexus, and is throughout in close relation with the gut and its chloragogen cells. It becomes smaller in segment xii and very soon disappears.

The hearts are two pairs, in segments ix and $\mathrm{x}$. The first pair originate above from the supra-intestinal vessel, pass downwards close to the gut, then, taking a backward course, leave the intestine and perforate septum $\frac{9}{10}$ separately; continuing parallel for a short distance, they then unite in $\mathrm{x}$ to form the ventral vessel. The second pair appear to be more tortuous and of rather smaller calibre; they originate above from the dorsal vessel, which is here on the left side, so that the heart of the right side arches over the intestine; they pierce septum $\frac{10}{11}$ separately (this septum 
thus transmits three vessels ventral to the intestine) and unite with the ventral vessel in $x i$. Where the hearts join in the ventral vessel there are in both segments ( $x$ and xi) projections of cells into the lumen; these may, according to the evidence of sections, entirely block the cavity of the vessel.

Lastly, the anterior loops occur in segments ii-viii; they are non-contractile, and the posterior are larger than the anterior; in vii they are of about the same size as the dorsal or the ventral vessel, and in viii they are so large as to resemble the hearts. In ii-vii they run from the dorsal vessel to the anterior ventral, or to the branches which unite to form the latter; in viii, as already said, they run from the supra-intestinal to the anterior ventral. They give branches to the body-wall, which in vi, vii, and viii are of moderately large size. It may be added that the dorsal vessel also gives considerable branches to the body-wall in vi and vii, and the parietal vessels form a plexus in the prostomium and most anterior segments. Behind segment iv the parietal vessels have a longitudinal course, running parallel and fairly close together, so that about 20 such vessels are visible on examining the dorsal surface of the worm; there would thus be about 40 longitudinal vessels in all at any particular level, each of which runs through several segments without losing its individuality; this arrangement, as before noticed, ceases at the gill region.

The only other feature which I propose to select for special mention is the presence of remarkable giant fibres in the ventral nerve cord. They may be seen throughout the body on the dorsal side of the cord. They are of different sizes; the larger appear as tubes in transverse section, with a roughly circular or oval outline; a part of their lumen is always empty, and a part, to one side, is occupied by a substance which sometimes has the appearance of a fairly solid mass, sometimes that of a thin coagulum; the shape of this contained matter varies, being sometimes ovoid, sometimes quite irregular; at times it is connected here and there with the wall of the tube by a number of branching threadlike extensions; sometimes it occupies a considerable portion, sometimes very little of the lumen (figs. 3, 5, 6). Other fibres, also running longitudinally on the dorsal and dorso-lateral surface of the cord, are not tubular, and in their staining reactions somewhat resemble muscle fibres.

The number of these large fibres varies from place to place; there are in all, in any section, about five to ten ; they are most often six or seven in number, of which one to three have the tubular appearance described alove, the rest being larger or smaller solid fibres.

The actual size of the tubular fibres also varies. One is generally larger than the others,--in the posterior part of the body very much larger,--and this one is there constantly to the left of the middle line. These fibres are on the whole larger towards the hinder end of the animal; in the anterior segments they average about $20 \mu$ in diameter; as the gill region is approached they may be $40 \mu$; while posteriorly one, but only one at any given level, may be as much as $71 \mu$; these large fibres are, however, much constricted at the septa in this region, c.g. to about $15 \mu$ or even much less. 
The fibres are thus very conspicuous in sections through the posterior part of the body, and especially so is the largest fibre of the group (fig. 3), not only because of its actual size, but because, the whole section being so much smaller, it occupies relatively a far larger space than is the case anteriorly; its diameter may be nearly as great as that of the whole nerve cord, and may actually be greater than that of the ventral vessel close to it.

I am inclined to think that these fibres, or at any rate the specially large one, were seen by BEDDARD and described by him as the dorsal vessel. As will be seen, his description of the dorsal vessel is altogether at variance with the condition found by me, while it corresponds exactly to that of the large giant fibre.

The dorsal vessel is described by BEDDARD as being below the partition dividing the colom into upper and lower parts; as having thicker walls, and much less blood in the lumen, in sections, than the ventral; the blood in the dorsal vessel is, he states, never so darkly stained by carmine as the blood in the ventral vessel, to explain which he supposes that possibly the muscular walls of the dorsal vessel are particularly im. permeable to the staining fluid; when fully expanded the dorsal is stated to be of about the same calibre as the ventral vessel, but in certain parts its lumen was so contracted that the vessel could only with difficulty be recognised; the openings of the branchial vessels into the dorsal vessel were not seen, since at the point where these vessels should open it always happened that the dorsal vessel was very much contracted, while the end of the branchial vessel was much dilated (i.e. the dorsal vessel, according to BEDDARD's interpretation, would thus have a regularly moniliform shape, being contracted almost to obliteration once in each segment).

From my description, however, it appears that the dorsal vessel is above the incomplete muscular partition of the colom, and has no close relation to the ventral nerve cord; its lumen is in my specimens always full of blood, which has the same staining reactions as blood elsewhere (this, of course, is only what would be expected in sections stained on the slide); I found the dorsal to be often, if not usually, of greater calibre than the ventral vessel; the openings of the vessels into it were always well marked and patent, and there were no constrictions of importance along its course.

The specially large giant fibre, on the other hand, is below the coelomic partition, and has the relation to the nerve cord described by BEDDaRD for the dorsal vessel (on the left side just above the cord); the contents of the tube, which usually have the appearance of a coagulum, do in fact stain differently from the blood in the vessels; in diameter it is seldom (and only at the posterior end) as large as, or larger, than the ventral vessel; and at the septa it is regularly much constricted, so as to be, in the posterior portion of the animal, moniliform; while, of course, no vessels are to be seen opening into it.*

* The appearance of giant fibres has led other observers also to consider them as tubes containing a coagulable substance, e.g. SEMPER, who also found that the coagulum reacted to stains quile differently from blood-plasma; in the crayfish the fibres have been held to be blood-vessels. Compare Ashwortr (1), section ii., "Historical Account of the Giant Cells and Giant Fibres of Annelids."

TRANS. ROY. SOC. EDIN., VOL. XLVIII. PART II. (NO. 15). 
I have only a few remarks to make on the other systems. The alimentary canal is a fairly uniform tube throughout, showing little differentiation into distinct regions. The pharyngeal epithelium is markedly ciliated ; chloragogen cells begin in segment vi, and cease in the anterior gill region; the canal becomes somewhat wider in segment $x i$, from which point it may be spoken of as intestine; the anus is dorsal. The 'septal glands,' in segments iii, iv, and $v$, are collections of cells, not massed together in definite lobes, but surrounding the alimentary tube on all sides in the posterior part of each of the three segments; the septa are here bulged backwards, and the funnel-shaped space so formed is filled with the cells (fig. $2, p$ ). The glands are thus, apparently, merely collections of peritoneal cells.

The nephridia are long, closely coiled tubes, with a pear-shaped reservoir near the external aperture; the reservoir is less marked in the posterior nephridia. They begin in segment xii, and cease from fifteen to thirty segments in front of the posterior end; the external apertures are in line with, and in front of, the ventral setal bundles, near the anterior margin of each segment.

The cerebral ganglion is deeply indented anteriorly, less so behind; the dorsal vessel, here divided, is closely applied to its under surface. The ventral nerve cord is relatively very large in the posterior part of the body (fig. 5), and may be equal in diameter to the intestine; it is even absolutely larger than in the (much thicker) anterior part of the body; thus in one specimen, when sectioned, the transverse diameter of the cord was $61 \mu$ anteriorly, $110 \mu$ where the gills commenced, and $82 \mu$ in the posterior gill region.

Unfortunately none of my specimens were sexually mature. Testes were present in $x$, and ovaries in $x i$, and in one specimen the male deferent apparatus was beginning to form, in the shape of a funnel on septum $\frac{10}{11}$, while a backward pouching of the same septum indicated the commencement of the vesicula seminalis; but there was nothing distinctive to be discovered.

\section{Limnodrilus socialis, sp. nov.}

The mode of occurrence of this worm has already been described. On a subsequent occasion I found it even more abundantly in the same locality; the small pools were beginning to dry up, and the water was everywhere very foul ; the worms occurred in large tangled masses of sometimes several pounds in weight, their tails waving as before; a considerable proportion were sexually mature on both occasions (December and February). Again, on March 1st, there were still numbers of the worms in the mud of the nullah; a quantity of these were taken, and on examining them I was surprised to find that the large majority were headless, the whole of the anterior segments, including all the genital organs, having disappeared. Thus, in each of two batches of over fifty individuals, only four complete specimens were found. The worms nevertheless behaved as usual, waving their posterior ends, and contracting on being disturbed; when isolated 
in a dish they appeared to move and coil themselves up in the same way as perfect individuals (see below).

A possible explanation of this curious circumstance seems to be that by the expulsion of the genital products, which apparently takes place towards the end of February, the anterior segments of the body are so much damaged that they die and are thrown off; the worms, however, continue to live, though it may be doubted whether they are capable of regenerating the anterior end; probably they die after a time, and the whole generation thus perishes each year.

On touching any part of a mass of these worms they cease their waving movements ; a feeble disturbance merely causes them to hold themselves rigid, while a more violent one causes a general contraction of all the individuals. Contraction also takes place if the mud near them be disturbed. It looks, at first sight, remarkably easy to scoop up a number of the worms; but as soon as the spoon touches the mud the waving tails vanish in a flash, and however quickly the scoop be made, probably few will be obtained. This, of course, is not the case with the large masses described above, which are so tightly intertwined that they cannot escape thus. The same waving movements and sudden contractions are seen in the worms kept in a vessel in the laboratory, where a slight jarring of the table is sufficient to arrest the movements. Isolated individuals usually coil themselves up into a spiral on being disturbed.

External features.-The usual colour is a pale reddish brown, deeper anteriorly than posteriorly; by reflected light under a low-power binocular microscope the posterior part of the body often has a patchy, opaquish yellow colour, which has the appearance of being due to a golden-bright granular deposit on the inner surface of the body-wall; it is probably in reality a deposit in the peritoneal cells. Some specimens from the foul pools mentioned above were black in their posterior half; and it may be mentioned, by way of comparison, that I have found Clitellio arenarius, usually of a red colour, completely black when inhabiting a part of the shore contaminated by sewage.

The length of the worms when extended may be as much as three inches; smaller specimens measure one and a half or two inches. Their greatest breadth is less than a millimetre. 'The number of segments is commonly about 110 ; there is a double annulation in the first few. The prostomium is bluntly conical. The clitellum includes the eleventh with more or less of the twelfth segment.

The setæ (fig. 9) of both dorsal and ventral bundles begin in segment ii, and are of the same form. They are moderately stout, have the usual double curve, and are bifid distally; the proximal prong of the fork is shorter and stouter than the distal (about three-quarters as long, and one and a third times as thick at the base); the nodulus is distal to the middle of the length of the shaft (proximal : distal $:: 3: 2$, or thereabouts). The length of the setæ in the anterior part of the body is about $115 \mu$, but posteriorly it is less, the average being about $80 \mu$. The number of setæe per bundle is six, seven, or eight in the anterior part of the body, diminishing to three or four posteriorly.

In the first few segments the prongs of the fork may have a slightly different 
character, being longer and separated by a smaller angle than elsewhere. In the eleventh segment the ventral setæ are absent, their position being occupied by the male aperture.

The body-wall (figs. 10,11) consists of the usual layers. In addition to the circular and longitudinal muscular layers, there is regularly present a well-marked muscular band, passing vertically through the body-cavity, between the dorsal and ventral setal sacs of the same side in each segment (fig. 10). The peritoneal cells lining the inner surface of the body-wall have a distinctive character (figs. 10,11); they are fairly large, ovoid, and transparent; in sections they are very slightly coloured, the only part of the cell-body which takes up the stain being a quantity of contained granular matter; the circular or oval nucleus, with a well-marked nucleolus, is conspicuous ; they resemble chloragogen cells, but are without the numerous yellow particles which characterise these latter. Similar but larger cells, pyriform in shape, attached by their stalk-like narrow ends, are also found on septa $\frac{6}{7}$ and $\frac{7}{8}$, and round the nephridia of segments vii and viii. There is a lateral line (fig. 10), similar to that described for Branchiura sowerbyi (see p. 289); the cells composing it extend peripherally outwards as far as the circular muscular coat, and divide the longitudinal layer along a line which runs midway between dorsal and ventral setal bundles; in this worm, however, the lateral line is well marked only in the anterior segments. No free calomic corpuscles were seen, except a few yellow granular cells, which were probably detached chloragogen cells.

Alimentary canal. - The pharynx extends backwards through the third segment; its tall columnar epithelium, as also that of the œsophagus, is ciliated. From the third to the seventh segment the ventral wall of the canal is raised into a prominent longitudinal ridge, due to the greater height of the epithelium along this tract (fig. 11); the lumen is thus crescentic. Chloragogen cells begin in segment $\mathrm{v}$.

As appendages of the alimentary canal may be mentioned paired masses of cells in segments vi and vii. These are situated in the anterior part of the segment, ventrolaterally to the osophagus; in transverse section they have a pyriform shape, with the small end below, near the ventral vessel, and the glands of the same pair may unite with each other round the vessel (fig. 11). Some of the cells contain yellow granules like those of the chloragogen cells, but their general character is very different from that of these latter, inasmuch as they are more compact, more irregular in size and shape, and stain more deeply in both cell-body and nucleus; moreover, though they are in contact with the chloragogen cells, they do not merge into them, and the masses have a distinct outline of their own. Similar but smaller aggregations were also found in segments $\mathrm{v}$ and viii.

The circulatory system (figs. 12, 13, 14) is of considerable interest. The dorsal vessel is ventral in position for the greater part of its course; it runs alongside and on the left of the ventral vessel; both are sinuous, the ventral vessel more markedly so; the convexities of their curves face away from each other. The dorsal vessel is somewhat laterally situated in segments $x i$ and $x$; it becomes more ventral again in ix, only to 
leave the ventral surface altogether and reach the dorsal side of the oesophagus in viii. The vessel is surrounded by chloragogen cells, and is situated in close contact with the intestinal wall, as far forwards as ix; it then separates from the alimentary tube and becomes free in the body-cavity. It is contractile throughout its length.

BEDDARD (3) mentions a ventral position of the dorsal vessel as a rare peculiarity among the Oligochæta, which is found in the genera Branchiura and Dero. It is a curious coincilence that these two worms were found in association with the species under description, as related previously.

The supra-intestinal vessel can be traced in the living animal as well as in sections as far forwards as the anterior part of segment $v$. It is covered by chloragogen cells throughout its course; in the anterior part of its extent it appears in transverse sections as a fusiform space, a special channel of the gut plexus; it is large in segment vii ; in segment viii it may, in the living specimen, be hardly visible (perhaps from accidental causes), or, on the other hand, it may be large and conspicuous; in sections it is here larger than either the dorsal or the ventral vessel.

In the anterior part of segment ix, situated transversely like a half ring on the dorsal side of the intestine, is a sinus-like blood-space, with the following connections (figs. 1.2, 13). Posteriorly it dissolves into a close network of small vessels in the intestinal wall. On the right side it is in open communication with a large vessel in the gut wall, which runs along the right side of the alimentary tube, gradually dying away, and becoming indistinguishable posteriorly at about segment xxi, while anteriorly it ceases as a distinct vessel in segment viii ; this, again, though a perfectly distinct, and indeed a very conspicuous, vessel in the living animal, is covered by chloragogen cells, and appears in sections as a special channel of the intestinal plexus. Anteriorly the sinus in segment ix may in favourable cases in the living worm be seen to be connected with the supra-intestinal vessel, though the channel of communication through septum $\frac{8}{9}$ seems as a rule to be of inconsiderable width. 'The above lescription is confirmed by sections; the supra-intestinal can be traced as a well-marked vessel up to the septum, where all blood-channels are constricted; on the other side of the septum there is no longer a supra-intestinal vessel, but a sinus encircling the upper half of the gut, from which, on the right side, the vessel described above takes origin.

The intestinal plexus, which has already been referred to, extends throughout the length of the intestine, and reaches as far forwards as segment jv. For some distance behind the genital segments it is fed on the left side by a conspicuous series of branches, one in the anterior part of each segment, from the dorsal vessel ; and on the right side by twigs from the channel described above as running along the right side of the intestine (fig. 14).

The hearts (figs. 12, 13) are a single pair of vessels, which arise from the supraintestinal anteriorly in viii, pass obliquely downwards and backwards, pierce septum $\frac{8}{9}$ and gradually converge, to unite about the middle of segment ix. When full of blood 
their anterior ends are much swollen; their contractions are alternate, pass downwards and backwards, and have no time-relation to the contractions of the dorsal vessel.

The genus Limnodrilus possesses in general two pairs of hearts ; the present species is therefore remarkable in having only one pair. There is, however, in the sexual animal a special loop to the genital organs, including the seminal vesicles and egg-sac. There is no trace of any such ressel in the non-sexual animal as a rule; on one occasion, however, in a specimen in which no genital organs were discoverable, a loop was seen in segment ix ; this specimen was perhaps just about to develop sexual organs. The loops develop along with the organs they supply, and soon extend backwards from segment ix in complicated windings; in the fully developed sexual animal they may extend as far as $x v i$,--in one case two segments behind the posterior limits of the genital sacs, here appearing to be applied to the wall of the intestine; they end ventrally in segment $x$ by joining the ventral vessel (fig. 12). The loops are contractile, and it is a fascinating occupation to watch the wave of contraction wandering along the complicated windings of the loop through segment after segment. It seems not impossible, therefore, to compare these genital loops with the second pair of hearts of other species of Limnodrilus; they would be hearts developed only at sexual maturity, greatly increased in length, and modified for their special function. I have no actual note of their dorsal origin ; it is, however, presumably from the dorsal vessel, since the supra-intestinal does not exist behind segment viii.

The ventral vessel (fig. 12) is formed anteriorly at about the level of septum $\frac{4}{5}$ by the union of a pair of vessels, one on each side, coming from the front end of the animal. After receiving the lateral loops of segment vii it becomes smaller, and in the next part of its course it appears to be variable. In the living animal it was seen on one occasion to be continued as a fair-sized vessel to the junction of the hearts in ix, and so onwards after being thus reinforced. In three other cases it became very narrow; but close observation at times when it was filled with blood showed that it was here also continued to join the angle between the hearts, or to one or other heart immediately in front of the junction. In other cases no connection could be made out, nor could any such channel be discovered in either of two series of transverse sections; in these cases the vessel ended on the intestine in front of septum $\frac{8}{9}$, sometimes bending to the right, towards the anterior end of the channel in the right wall of the intestine ( $v$. sup.) before disappearing.

The condition therefore resembles in some degree that described in Bothrioneurum and Lophochrta ( $c f$. BEDdaRd, 3, p. 70), where the ventral vessel of the anterior segments is continued backwards on the intestine as a 'subintestinal' vessel, while there is a fine channel of communication between this subintestinal vessel and the point of union of the hearts. The specimens in which the connection between anterior and posterior parts of the ventral vessel is altogether wanting show a condition similar to that described above for Branchiura sowerbyi ; and with this, again, may be compared Tubifex costatus (Heterochrta costata), Clap. (10), the only difference being that in 
this latter species the 'anterior ventral' is continued backwards for a short distance on the intestine, beyond the level of union of the hearts.

To return to the course of the ventral vessel in the species under description : the vessel formed in segment ix by the junction of the hearts extends to the posterior end of the body ; it is more sinuous than the dorsal vessel; it is situated on the right of the nerve cord, the dorsal vessel being on the left. It is less intimately united to the intestine than the latter, not being covered by chloragogen cells; it is somewhat widely separated from the intestine in the genital segments.

The lateral commissures in front of the hearts form an elegant tracery of complicated loops. In the posterior part of the body the loops run on the anterior face of the septa, and give branches outwards to the body-wall, which form the cutaneous plexus. This extends through about the posterior half of the body; it consists of a number of fair-sized vessels which penetrate the muscular coats, and so come to lie between the cells of the surface epithelium. There are four chief capillary vessels on each side in each segment, at about equal distances from each other ; the condition may therefore be compared with that in L. hoffmeisteri, as described by VEJDovsKY (11, p. 116, and plate vii. figs. 16,17); the special mode of branching there described is not, however, found in the present species; there is no collection of chloragogen cells round the origin of the cutaneous branches; and the cutaneous vessels in the form under description branch freely and anastomose. Though sometimes the secondary branches seem to come to a blind end, this is probably due to the pressure on the specimen, and I do not think they ever really end blindly.

Nephridia are present in segments vii and viii; there is then a hiatus as far as segment xiii. Thenceforwards, too, they are not present in every segment; three or more consecutive segments may possess nephridia, and then they may be absent from one or two; two or three more will have them, and so on; but there is no general rule as to their distribution. The funnel is small, with long cilia round its margin; these wave slowly and languidly; but a few long flame-like flagella, arising from within the funnel and beating down the tube, are much more active; these flame-like flagella are repeated several times in the course of the tube. The tube itself is long, loosely coiled, without a terminal vesicle; it ends on the surface immediately in front of and lateral to the setal sac. The peculiarity of the nephridia of segments vii and viii -that they are surrounded by large pear-shaped peritoneal cells-has already been mentioned.

The cerebral ganglion is deeply eleft in front, slightly so behind (fig. 15).

The reproductive organs were well developed in a considerable number, perlaps in the majority of specimens. The testes are in $\mathrm{x}$, attached by a narrow base to the junction of septum $\frac{9}{10}$ with the ventral body-wall. The funnel is also in $x$, on the opposite septum; it has the usual characters. The vas deferens is in $\mathrm{xi}$; it is long and much coiled, wider in its first than in the later part of its course $(39 \mu$ as against $27 \mu$ later); its lumen is also relatively and absolutely greater, and its walls stain 
less deeply, in its first part. The cells of which its wall is composed have nuclei which are much elongated transversely to the axis of the tube; their length may be as much as one-third of the circumference. The vas deferens is continued into the atrium, which begins in the posterior part of $\mathrm{xi}$, the septum $\left(\frac{11}{1} \frac{1}{2}\right)$ being here much bulged backwards. The atrium is of an elongated pyriform shape, its first part being the broader $(90 \mu)$; the lumen is at first small, or even, in transverse sections, invisible ; only the basal portions of the cells take the stain. The penial end of the atrium is narrower, the lumen is more distinct, the whole of the cells are deeply stained so as to obscure the nuclei. The prostate is a fairly large, somewhat spherical cellular mass, continuous with the wall of the atrium, to the first part of which it is attached, a little way beyond the end of the vas deferens. The atrium joins the penis, which lies in a canal directed forwards and downwards to the male aperture. This canal is narrow and cylindrical, wider near its external termination, contracting again, however, at the actual aperture, which is situated ventrally on $x i$, in the position of the missing setal sacs. The penis itself is surrounded by a chitinous penis sheath lying loosely within the canal. The sheath is tubular, circular in cross section, narrowing gradually along its course, but expanding again and curving forwards at its outer end; its length is about $520 \mu$, its breadth $49 \mu$ above, at its narrowest part $28 \mu$. The lower side of its expanded end terminates in a free margin; the upper side is curved strongly upwards and joins the wall of the penis canal (fig. 16); in the section there illustrated a horizontal cellular shelf projects backwards into the open end of the penis sheath. The sheath ends some distance above the external aperture of the penis canal. The vesicula seminales comprise a pair of sacs in ix, forward bulgings of septum $\frac{9}{10}$, and a long single sac extending back through xi and a number of succeeding segments, which is essentially a backward bulging of septum $\frac{10}{11}$.

The ovaries in segment xi correspond in position to the testes; they are large, extending upwards at the sides of the alimentary canal, and becoming dorsal to it. The funnel is situated ventrally on septum $\frac{11}{12}$; the oviduct is a minute passage leading to the exterior in the inter-segmental constriction between xi and xii. The ovisac extends backwards in the same way as the sperm-sac. The spermathecx are in segment $\mathbf{x}$; their external aperture is just in front of and in line with the setal sacs. At first the passage runs vertically; its lumen here is narrow, and its epithelial lining consists of deeply staining cubical or low columnar cells, with a cuticle on their free surface. The height of the epithelium soon becomes irregular, and the outline of the lumen in consequence wavy. All this first part, or duct, is invested by a strong muscular covering, in two layers, a longitudinal external and circular internal; its diameter is about $80 \mu$. After bending about, the cavity widens very considerably; the lining consists of a rather irregular layer of low columnar cells, and the lumen is filled with a granular coagulum; the diameter of the ampulla is about $270 \mu$. There were no spermatophores.

The diagnosis of the genus Limnodrilus, as given by Mrchaelsen (5), runs as follows:- "Ventrale und dorsale Biindel lediglich mit gleichartigen, gabel-spitzigen 
Hakenborsten. Männliche poren am 11, Samentaschenporen am 10 segm. Supraintestinalgefäss und Subintestinalgefäss vorhanden; Transversalgefässe des 8 und 7 Segm. herzartig: integumentaler Blutgefässplexus meist vorhanden, aber spärlich. Nephridien mit Endblase. Hoden im 10 Segm.; Samenleiter lang, in das proximale Ende der Atrien einmündend; Atrien mit einer grossen Prostata; Penis mit Chitinscheide. Samentaschen im 10 Segm. Spermatophoren in den Samentaschen."

The present, therefore, differs from other species of the genus in the absence of a subintestinal vessel; in the presence of only one pair of hearts; in the absence of a terminal dilatation of the nephridial canal ; and apparently in the ventral position of the dorsal vessel. But having regard to the rest of the anatomy, especially the characters of the setæ, of the genital organs, including the chitinous penis-sheath, and the cutaneous blood-plexus, there can be little doubt that it should be included in the genus.

Of the species within the genus, it resembles most closely L. hoffmeisteri, Clap., with which it appears to be very similar in its general appearance, size, number of segments, number of setæ per bundle, characters of brain and pharynx. None of these, however, are particularly distinctive; more striking are the investment of the anterior nephridia with bladder-like (blasenförmigen) cells, and the number of cutaneous twigs per segment. The general proportions of the penis-sheath are much the same; but the curve of the tube and the character of its mouth differ considerably ( $c f$. VEJDovsKY, 11, pl. xi. fig. 4). The mode of origin of the cutaneous capillaries, the fact that they do not end blindly in the present species, and that the dorsal and ventral vessels are, as usual, on opposite sides of the alimentary tube in L. hoffmeisteri (cf. VEJdovsky, op. cit., pl. viii. figs. 16, 17), on the same side in this species, as well as, presumably, the points given above wherein this species differs from all others of the genus, also serve to distinguish them.

I propose the following diagnosis:-Colour pale reddish brown; length 40-75 $\mathrm{mm}$.; segments about 110 , double annulation in the first few ; prostomium bluntly conical ;

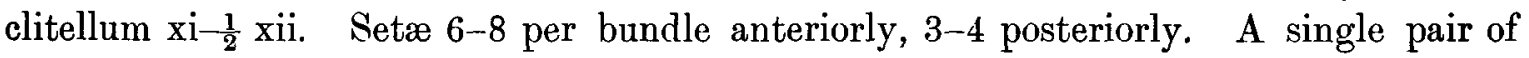
hearts in viii ; dorsal vessel is ventral in position, to left of ventral vessel, from posterior end as far as genital segments; no subintestinal vessel. Nephridia in vii and viii invested with large pyriform peritoneal cells; no nephridia in ix-xii; not present in every segment from xiii onwards. Cerebral ganglion deeply cleft in front, slightly so behind. Chitinous penis-sheath 10-11 times as long as its widest part is broad, curved forwards at its lower end, where its anterior lip is strongly reflexed upwards. 


\section{REFERENCES TO LITERATURE.}

(1) Ashworth, J. H., "The Giant Nerve Cells and Fibres of Halla parthenopeia," Phil. Trans. Roy. Soc. Lond., series B, vol. cc. (1909).

(2) Beddand, F. E., "A new branchiate Oligochæte (Branchiura soverbyi)," Quart. Journ. Micr. Science, N.S., vol. xxxiii. (1892).

(3) Beddard, F. E., A Monograph of the order Oligochæta, Oxford, 1895.

(4) Bourne, A. G., "On Chætobranchus, a new genus of Oligochætous Chætopoda," Quart. Journ. Micr. Science, N.S., vol. xxxi. (1890).

(5) Michaelsen, W., "Oligochæta," in Das Tierreich, Berlin, 1900.

(6) Michaelsen, W., "Zur Kenntnis der Tubificiden," Arch. fïr Naturgesch., vol. lxxiv., Bd. i., Heft 1, Berlin, 1908.

(7) Mrohaelsen, W., "Die Oligochätenfauna der vorderindisch-ceylonischen Region," Abh. aus dem Gebiete der Naturw. hgbn. vom Naturw. Verein in Hamburg, Bd. xix., Heft 5 (1910).

(8) Perrier, LÉon, "Une station rhodanienne de Branchiura soverbyi Bedd.," Ann. de l'université de Grenoble, tome xxi., no. i., Paris, 1909.

(9) Stephenson, J., "Studies on the aquatic Oligochæta of the Punjab, I.," Records of the Indian Museum, vol. vo, part i. (1910).

(10) Stephenson, J., "On some littoral Oligocheta of the Clyde," Trans. Roy. Soc. Edin., vol. xlviii., pt. i. (1911).

(11) Vejdovskx, F., System und Morphologie der Oligochæten, Prag, 1884.

\section{EXPLANATION OF FIGURES.}

(Figs. 2, 3, 4, 5, 6, 10, 11, 16 drawn by camera lucida.)

Fig. 1. Single- and double-pointed setæ of Branchiura soverbyi. $\quad \times 450$.

Fig. 2. Section through anterior part of Branchiura soverbyji septum $\frac{4}{5}$, which is bulged backwards, is cut through in the upper part of the figure. Blood-vessels shaded. $\times 154$.

circ. m., circular muscular coat ; ep., surface epithelium ; in. circ. m., inner circular muscular coat ; $l . l$., lateral line cells; long. m., longitudinal muscular coat; m. set., dorso-ventral muscular bundle between setal sacs of same side; $x s$., œsophagus; $p$. , peritoneal cells ("septal gland"); $s$. , ventral setæ of segment iv; sept., septum $\frac{4}{5}$, consisting of decussating muscular fibres; v. n. c., ventral nerve cord, with giant fibre dorsally.

Fig. 3. Section through gill region of the same; the anterior face of the section is towards the observer, i.e. left and right are reversed. The longitudinal muscular layer is here broken up, leaving visible a fibrillar groundwork with a few nuclei. $\times 250$.

c., a group of cells connected with the ventral vessel, prominent in this particular section; chl., chloragogen cells; $d . v$., dorsal vessel, showing a connection with the enteric plexus; g.f., giant fibre, to the left of which, in the figure, are seen a row of similar but smaller fibres; int., intestine; plex., part of intestinal blood-plexus ; v. v., ventral vessel. Other references as above.

Fig. 4. Cells of the lateral line in the posterior part of the same, in transverse section. The lateral line is here discontinuous; where present the cells project some distance inwards and spread out. $\times 560$.

cht., cuticle ; int. ep., intestinal epithelium ; int. m., intestinal muscular coat ; per., peritoneal cells round intestine. Other references as above.

Fig. 5. Transverse section of the same near the extreme posterior end, showing the transverse muscular partition, the absence of a definite body-cavity in the ventral part of the section, and the relatively large size of the ventral nerve cord. $\quad \times 250$.

$m$., bands of muscle fibres, in various directions; transv., transverse band (the ceelomic partition); $x$, groundwork of fibrillæ and nuclei. Other references as before. 
Fig. 6. Section along a ventral gill, to show epithelial covering, continuation of circular muscular layer of body on the gill, gill cavity, and cells contained within it. $\times 250$.

a., branching cells within gill cavity; $b$. $v$., blood-vessel ; cav., gill cavity ; m., muscular strands coming down from the transverse partition. Other references as before.

Fig. 7. Branchiura sowerbyi; blood-vessels to the gills; from a sketch from life, from the right side; the dorsal vessel is therefore behind the intestine as seen by the observer. Of the two cutaneous branches shown, the one on the right is coming towards the observer and is superficial, the one on the left is on the deep surface.

cut., cutaneous branch; $d . g$., dorsal gill ; $d . v$., dorsal vessel ; int., intestine ; $v$. g., veutral gill ; v. v., ventral vessel.

Fig. 8. Transverse section through gill region of Branchiura sovverbyi ; diagrammatic, constructed from sections to show the course of a number of vascular branches, which are not on the same level. The dorsal vessel $d$. $v$. gives off a dorsally directed branch $d$. $d$. to the dorsal gill, and a ventrally directed branch $v . d$. to the ventral gill. The ventral vessel $v$. $v$. gives off a branch on the right side which bifurcates into a dorsal, $d$. $b r . v$, and a ventral division, $v, b r . v$, going to the dorsal and ventral gills respectively. The ventral vessel also gives off a branch ou the left side, $l . b r . v$.

$d$. g., dorsal gill ; ep., surface epithelium; int., intestine ; $i . p$. , intestinal plexus; $l . m$. , longitudinal muscular layer (the circular layer is not separately represented); v. g., ventral gill; $v . n$. c., ventral nerve cord.

The section is seen from its anterior face; right and left are therefore reversed.

Fig. 9. Seta of Limnodrilus socialis. $\times 750$.

Fig. 10. Part of transverse section through the fourth segment of Limnodrilus socialis, showing the lateral portion of the body-wall. $\times 250$.

circ. m., circular muscular layer ; cut., cuticle ; ep., surface epithelium; l. l., lateral line cells ; long. m., longitudinal muscular layer; $m$. set., muscular bundle between setal sacs of the same side ; per., peritoneal cells ; 8., setæ.

Fig. 11. Transverse section through sixth segment of the same. $\times 115$.

chl., chloragogen cells; $d . v$., dorsal vessel ; gl., gland-like masses of cells; oes., œesophagus with ventral ridge projecting into lumen; $s . i$. $v$., supra-intestinal vessel ; v. $n$. $c$., ventral nerve cord ; v. v., ventral vessel. Other references as above.

Fig. 12. Portion of vascular system of the same, from the right side; from a sketch from the living. The anterior and posterior parts of the ventral vessel are continuous by means of a fine channel; the transverse sinus is seen in ix, and a part of the contractile loop to the genital organs.

Fig. 13. Portion of vascular system of the same from above, showing the relations of dorsal and supraintestinal vessels, the hearts, the transverse sinus and its associated plexus ; from a sketch from the living.

Fig. 14. Blood-vessels on the left side of the intestine of the same; from a sketch from the living; the anterior end is towards the left. The dorsal vessel is shown below the intestine.

Fig. 15. Outline of cerebral ganglion of the same.

Fig. 16. Longitudinal section through lower part of penis tube and sheath of the same, to show the shape of the lower end of the chitinous sheath and its relations. $\times 250$.

circ. m., circular muscular layer; ep., surface epithelium ; long. m., longitudinal muscular layer ; per., peritoneal cells ; s., penis sheath ; $t$., penis tube ; $v$. def., vas deferens ; $x$., shelf-like projection into lower end of penis sheath. 
Stephenson: Branchiura sowerbyi, Beddard.-Plate I.
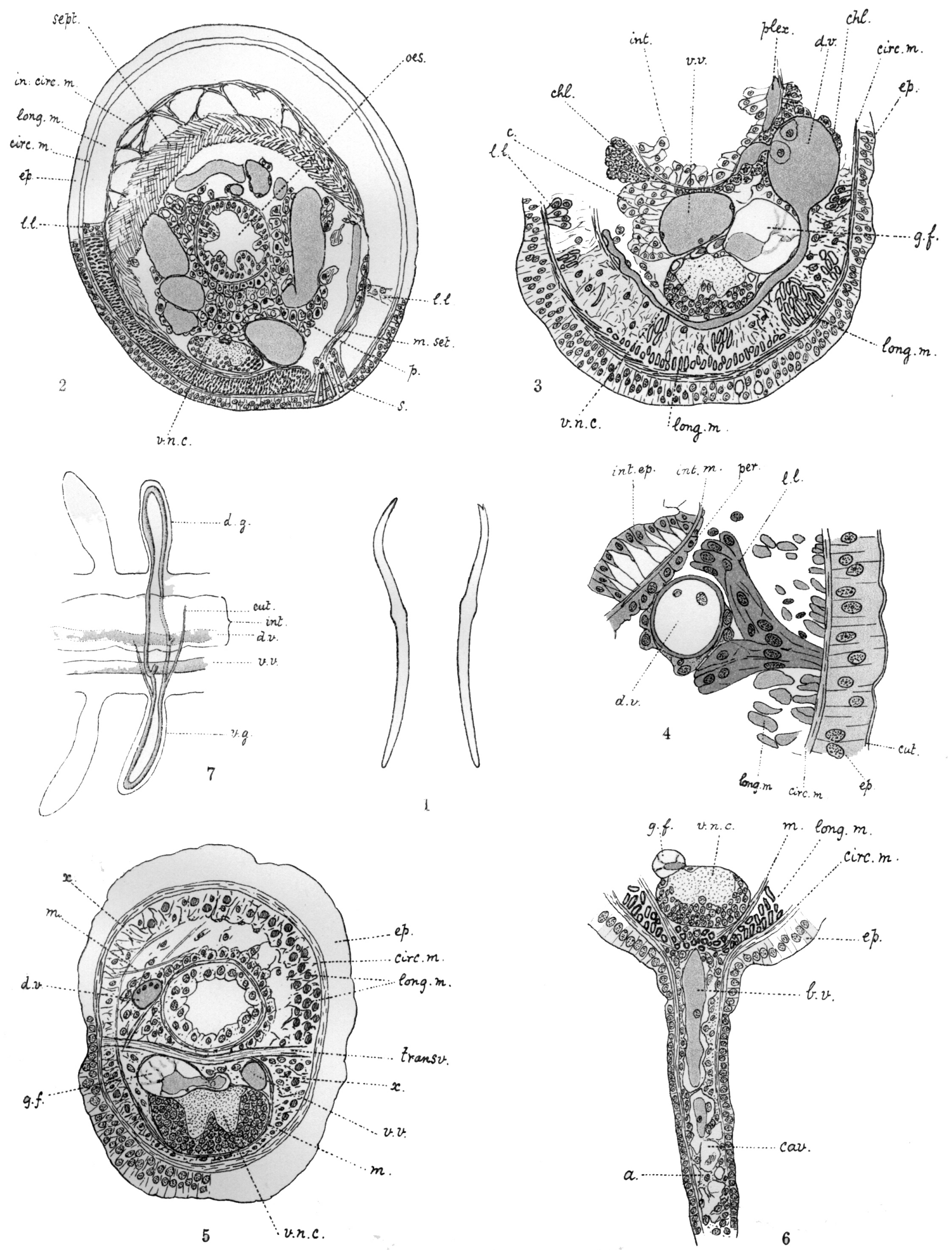

6 
Trans. Roy. Soc. Edin'.

Stephenson: Branchiura sowerbyi, Beddard.-Plate II.
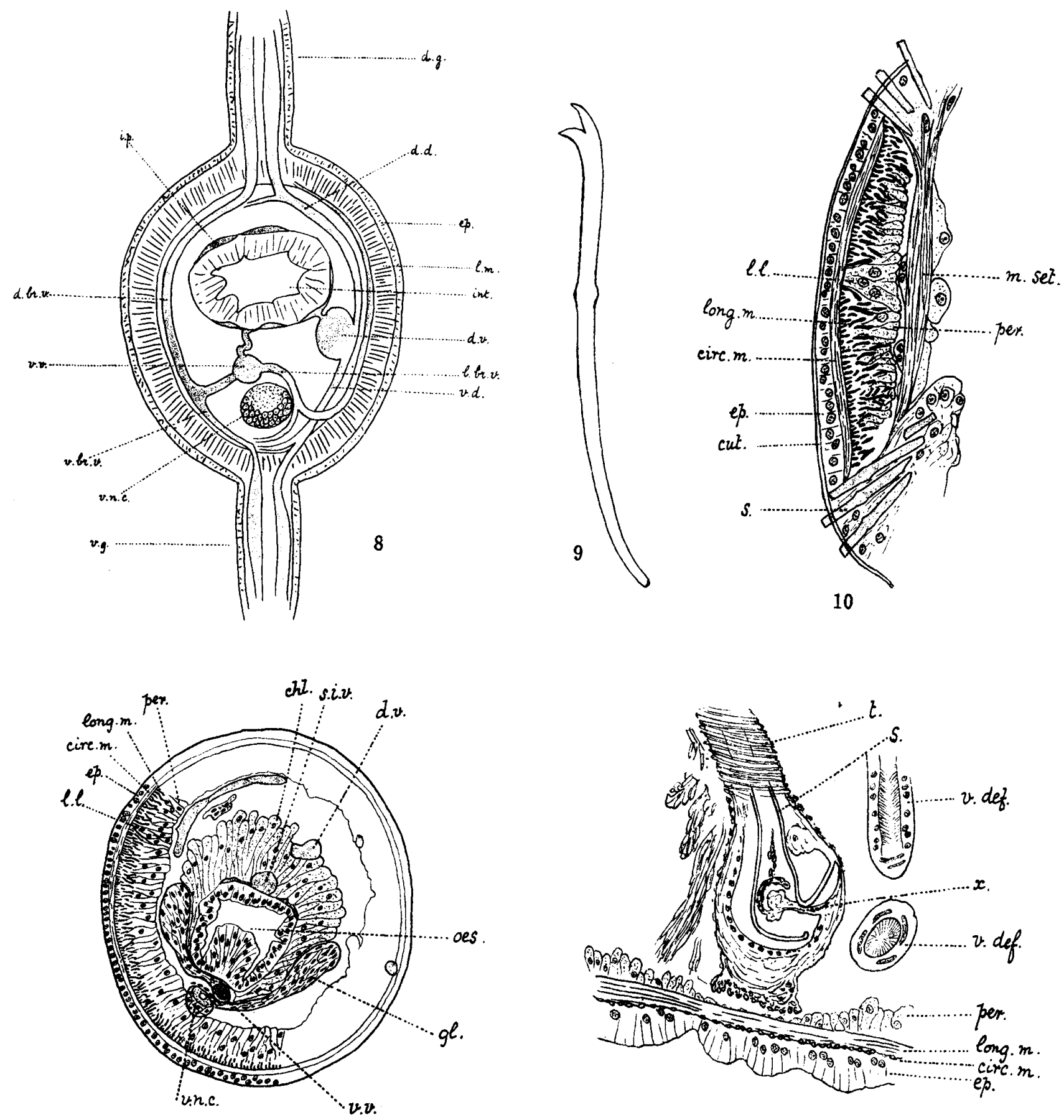

11
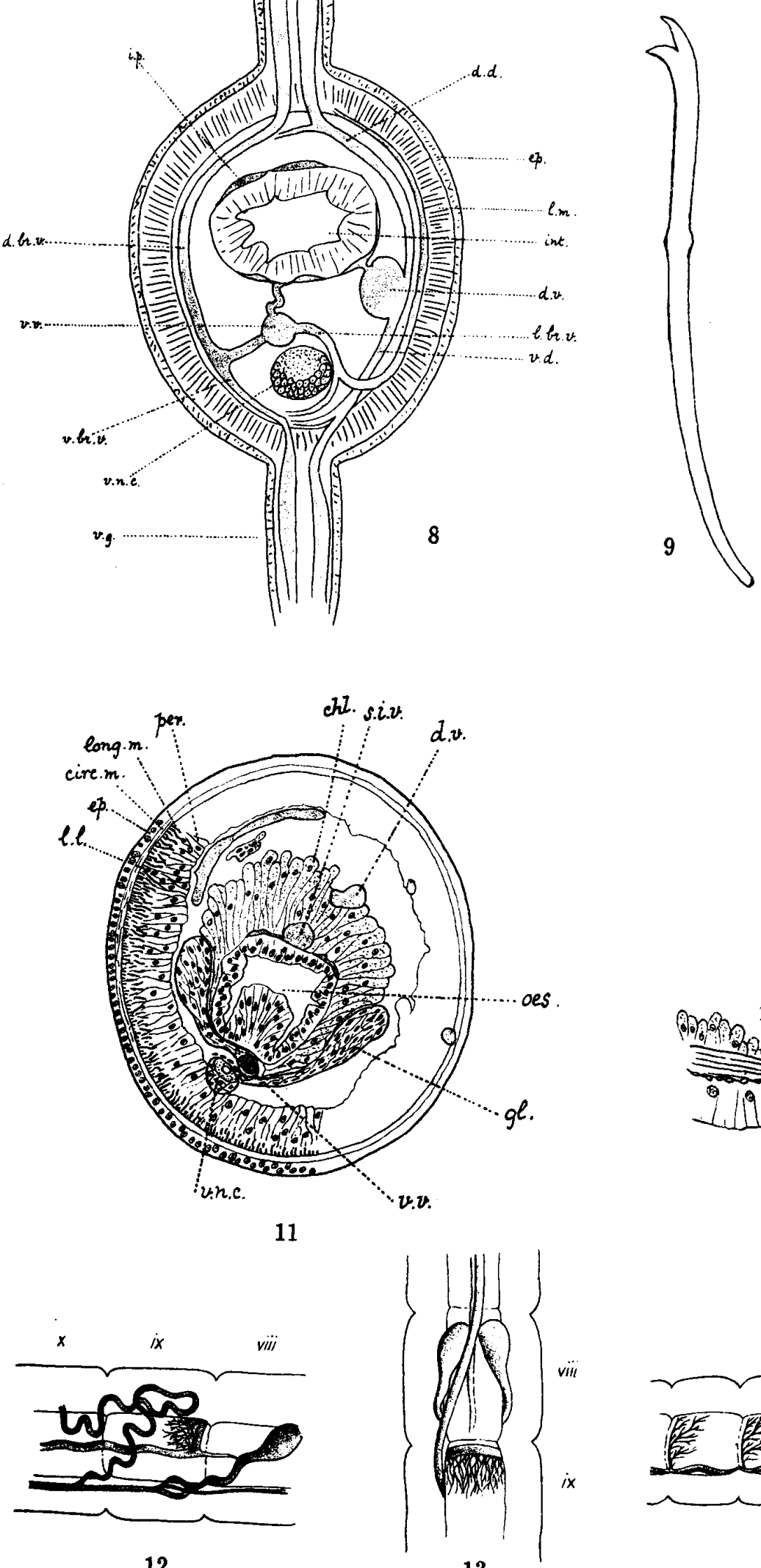

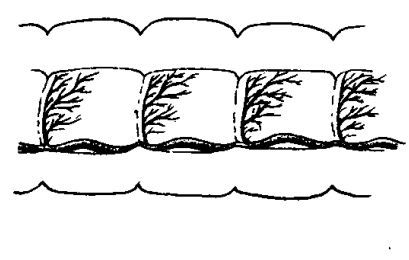

14

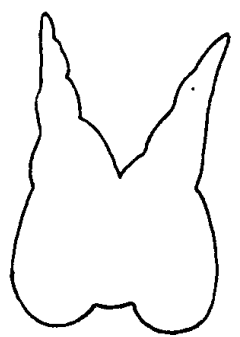

15 